\title{
Understanding Community Care
}


Also by Ann McDonald

Challenging Local Authority Decisions: Practitioners' Guide 


\section{Understanding Community Care}

A Guide for Social Workers

Ann McDonald 


\section{(C) Ann McDonald 1999}

All rights reserved. No reproduction, copy or transmission of this publication may be made without written permission.

No paragraph of this publication may be reproduced, copied or transmitted save with written permission or in accordance with the provisions of the Copyright, Designs and Patents Act 1988, or under the terms of any licence permitting limited copying issued by the Copyright Licensing Agency, 90 Tottenham Court Road, London W1P 0LP.

Any person who does any unauthorised act in relation to this publication may be liable to criminal prosecution and civil claims for damages.

The author has asserted her right to be identified as the author of this work in accordance with the Copyright, Designs and Patents Act 1988.

First published 1999 by MACMILLAN PRESS LTD

Houndmills, Basingstoke, Hampshire RG21 6XS

and London

Companies and representatives

throughout the world

ISBN 978-0-333-67592-2

ISBN 978-1-349-14280-4 (eBook)

DOI 10.1007/978-1-349-14280-4

A catalogue record for this book is available from the British Library.

Copy-edited and typeset by Povey-Edmondson Tavistock and Rochdale, England 
To Felicity, with love 


\section{Contents}

Acknowledgements xiii

INTRODUCTION

\section{CHAPTER ONE}

Social Work within Community Care 6

Policy development $\quad 7$

Social policy perspectives $\quad 7$

The social policy of community care 9

The social work task 11

Parallels with the Children Act $1989 \quad 13$

The legal framework of community care $\quad 15$

$\begin{array}{ll}\text { Clients, service users and consumers } & 17\end{array}$

Knowledge, skills and values $\quad 18$

$\begin{array}{ll}\text { The functions of social work } & 18\end{array}$

Models of practice $\quad 20$

Social work training $\quad 21$

\section{CHAPTER TWO}

The History of Community Care 23

The ideological $\quad 24$

The outcomes of research $\quad 25$

The economic $\quad 26$

Quasi-markets $\quad 27$

The mixed economy of care $\quad 28$

The economics of community care $\quad 29$

From policy to legislation $\quad 31$

Community care plans 31

Community care services $\quad 32$

Assessment and provision of services 33

Health service changes $\quad 37$ 
$\begin{array}{ll}\text { Education changes } & 39\end{array}$

$\begin{array}{ll}\text { Housing } & 40\end{array}$

$\begin{array}{ll}\text { The social security system } & 41\end{array}$

The criminal justice system $\quad 42$

The challenge for social work $\quad 42$

\section{CHAPTER THREE}

Needs-Led Assessment $\quad 44$

The statutory framework $\quad 45$

What is assessment? $\quad 45$

The assessment process $\quad 46$

Skills in assessment $\quad 48$

Assessment and working in partnership $\quad 50$

$\begin{array}{ll}\text { A due process model } & 51\end{array}$

Determining the level of assessment $\quad 52$

$\begin{array}{ll}\text { What are needs? } & 54\end{array}$

Recording and record keeping $\quad 55$

Assessment of carers $\quad 56$

\section{CHAPTER FOUR}

Care Planning $\quad 60$

A 'blueprint for action' $\quad 60$

Determine the type of plan 61

Explore the resources of users and carers 61

Establish preferences $\quad 62$

A critique of the applicability of accounting practices within community care $\quad 65$

Cost the care plan $\quad 67$

Agree service objectives $\quad 67$

Co-ordinate the plan $\quad 68$

Identify unmet need $\quad 71$

$\begin{array}{ll}\text { Record the care plan } & 72\end{array}$

Social work interventions: risk and protection; support and care

Risk and protection $\quad 73$

$\begin{array}{ll}\text { Support and care } & 76\end{array}$

$\begin{array}{ll}\text { Abuse issues } & 78\end{array}$

The nature and definition of the problem $\quad 79$ 
$\begin{array}{lr}\text { Prevalence and incidence } & 80\end{array}$

$\begin{array}{ll}\text { Social and professional abuse } & 80\end{array}$

The service response $\quad 81$

\section{CHAPTER FIVE}

Monitoring and Review $\quad 86$

$\begin{array}{lr}\text { Monitoring } & 87\end{array}$

Review $\quad 88$

What happens in practice? $\quad 89$

Evaluation and effectiveness $\quad 90$

Evaluating day care $\quad 91$

The social care model $\quad 92$

The continuing education model 92

Employment and work $\quad 93$

Leisure and recreation $\quad 93$

Influence of community care on day services 93

Evaluating home support services $\quad 95$

$\begin{array}{ll}\text { Evaluating residential care } & 97\end{array}$

\section{CHAPTER SIX}

Quality Assurance and Quality Control 99

Ways of defining quality 100

Trends within quality assurance and quality control 101

$\begin{array}{ll}\text { Measuring quality } & 102\end{array}$

Quality mechanisms in residential care $\quad 104$

Why regulate? 106

$\begin{array}{ll}\text { Outcome measures } & 107\end{array}$

Remedies in community care $\quad 109$

$\begin{array}{ll}\text { Complaints procedures } & 109\end{array}$

The informal stage $\quad 110$

The formal stage $\quad 110$

The review panel stage $\quad 111$

Ombudsmen $\quad 112$

Default powers $\quad 114$

Legal actions $\quad 115$

Private law rights $\quad 115$

$\begin{array}{ll}\text { Judicial review } & 117\end{array}$

The importance of challenge $\quad 118$ 


\section{CHAPTER SEVEN}

Changing Roles

Care management: can social work survive? 120

Working with other professions $\quad 122$

The status of social work within community care 124

Skills training in community care $\quad 126$

$\begin{array}{ll}\text { Social casework in community care } & 127\end{array}$

User satisfaction $\quad 128$

Care providers $\quad 129$

Carers' issues $\quad 130$

Community responses 133

\section{CHAPTER EIGHT}

Changing Values

What are values?

The historical development of social work values

CCETSW's values requirement

Values within community care 148

Participation

Empowerment 151

Advocacy 153

Anti-discriminatory and anti-oppressive practice $\quad 155$

Values in practice $\quad 155$

Working with black service users 156

Disability rights $\quad 157$

$\begin{array}{ll}\text { Mental incapacity } & 158\end{array}$

\section{CHAPTER NINE}

Financial Matters $\quad 163$

Charging for services 164

Direct payments $\quad 167$

$\begin{array}{ll}\text { Welfare benefits } & 170\end{array}$

Jobseeker's Allowance $\quad 171$

Income Support $\quad 171$

The Social Fund $\quad 172$

Retirement pensions $\quad 173$

Incapacity Benefit 174

Severe Disablement Allowance 174 
Disability Working Allowance 175

Disability Living Allowance and Attendance Allowance 175

$\begin{array}{ll}\text { Invalid Care Allowance } & 177\end{array}$

Housing Benefit $\quad 177$

$\begin{array}{ll}\text { Council Tax Benefit } & 178\end{array}$

Going into hospital or residential care $\quad 178$

Paying for residential and nursing home care $\quad 179$

Paying for long-term care $\quad 181$

Financial management $\quad 181$

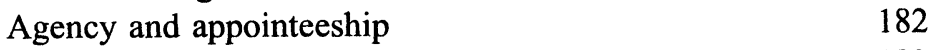

Ordinary and enduring powers of attorney 182

Receivership $\quad 183$

The social worker's role $\quad 183$

\section{CHAPTER TEN}

Social Needs and Health Care Needs $\quad 186$

The role of health care services $\quad 186$

Definitions of health care and social care $\quad 187$

Changes in the NHS 188

$\begin{array}{ll}\text { Continuing care } & 190\end{array}$

Hospital discharge $\quad 191$

Mental health 193

$\begin{array}{ll}\text { The care programme approach } & 194\end{array}$

The nature of hospital social work and the role of the social worker in a health care setting 197

The value of hospital social work 198

Working together in health and social care 199

\section{CHAPTER ELEVEN}

Social Needs and Housing Needs 201

Types of housing 201

Owner occupation $\quad 202$

Local authority housing $\quad 204$

Housing associations 205

Specialist housing and supported housing 205

Inter-agency collaboration $\quad 207$

Homelessness $\quad 210$

$\begin{array}{ll}\text { Residential care } & 214\end{array}$ 


\section{CHAPTER TWELVE}

Working in Adult Services $\quad 220$

Services for older people $\quad 221$

Learning disability services $\quad 223$

Physical disability services $\quad 224$

People with multiple impairments $\quad 227$

$\begin{array}{ll}\text { Transition services } & 228\end{array}$

Older people with learning disabilities $\quad 230$

Sensory impairments 231

Substance misuse $\quad 232$

HIV and AIDS 235

Mental health services 236

Implications of multi-agency working 239

$\begin{array}{ll}\text { CONCLUSION } & 241\end{array}$

$\begin{array}{ll}\text { Bibliography } & 245\end{array}$

$\begin{array}{ll}\text { Index } & 260\end{array}$ 


\section{Acknowledgements}

I would like to acknowledge, with thanks, the encouragement and help that I have always received from colleagues in the School of Social Work at the University of East Anglia, Norwich. Many friends, colleagues, practice teachers and students on the Dip. SW programme at UEA have contributed ideas and practical examples of their experiences of community care. I would particularly like to thank Kay Shail and Bill Wivell for their interest and support throughout the writing of this book. Undertaking such a substantial piece of work and seeing it through to its conclusion would have been impossible without the computer skills of Denys McDonald and the practical help of Georgina Henry-Routledge. Finally, I would like to thank my editor Catherine Gray for her encouragement and persistence.

ANN MCDONALD

Crown copyright material is reproduced with the permission of the Controller of Her Majesty's Stationery Office. 